\title{
Economic Valuation of Oil Palm Plantation Investment in Swamp Area of Tapin Regency, South Kalimantan, Indonesia
}

\author{
Hamdani Hamdani ${ }^{1}$ \\ ${ }^{1}$ Lambung Mangkurat University, Indonesia \\ Correspondence: Hamdani Hamdani, Department of Social Economic Agriculture, Faculty of Agriculture, \\ Lambung Mangkurat University, Indonesia. E-mail: hamdanifpunlam@yahoo.co.id
}

Received: October 24, 2015

Accepted: February 27, $2016 \quad$ Online Published: April 28, 2016

doi:10.5539/mas.v10n7p22

URL: http://dx.doi.org/10.5539/mas.v10n7p22

\begin{abstract}
This study describes the companies' feasibility determination on oil palm plantation investment. We also compare it with the oil palm plantation in swamp area, by considering economic, social and environmental aspects. We used total valuation method to valuing the environmental value of swamp area. Otherwise, investment analyzed by the model of benefit cost ratio (BCR), net present value (NPV), and internal rate of return (IRR). The study showed that the financial valuation of investment feasibility that is made and proposed by the plantation companies to banks (creditors), did not account the land value (economic, social and environmental values) of swamp ecosystems. The assessment on swampland value obtained Rp232, 570,833,400 or US\$24,481 million per year for 10,000 ha area - US\$2,448 per ha each year. Although the total value of economic environment is included in the valuation element of oil palm plantation investment in swampland, it still result insufficient value. However, by sensitivity analysis scenario of swampland plantation would become sufficient if the Crude Palm Oil (CPO) price is above US\$1300 per ton. It also has a second scenario if the environmental cost can be pressed optimally into Rp9, 025,541 or US\$950 per ha per year.
\end{abstract}

Keywords: economic valuation, investment feasibility, oil palm, swamp

\section{Introduction}

Oil palm (Elaeis gineensis Jacq.) as one of plantation commodity that is considered as superior by Government of Indonesia. Oil palm considered having crucial role in the national economic as the resources of income and foreign exchange for the state and job provider. The development area of this commodity grows rapidly. In 1970, the commodity area of oil palm is about 100 thousands ha, in 1980 reached almost 300 thousands ha, the next ten years (1990) reached 1.13 million ha, and in 2000 reached 4.16 million ha, then in 2010 reached 8 million ha.

South Kalimantan develops this commodity not only in the mineral dry land area, but also in the swampland area. But actually, the use of swampland area for agriculture in South Kalimantan has run since 200 years ago. Most of the community businesses are fishing and rearing, food crop (e.g. paddy) and horticulture, and duck and buffalo breeding. The others conduct business that still related to swampland use, such as trading, handicraft (fan, mat, and hat from Purun (Eleocharis dulcil) plants) (Sabran et al., 1999). So it can be considered that swamp and community has been long and strong related.

Swimpton et al. (2006), Noor (2007), Turpie et al. (2010), and Roy et al. (2012) explained that swamp is essential and unique natural resources due to its many benefits, not only economically. Swamp area functioned also as the water catchment area, production and propagation of living creatures (feeding ground, nursery ground, spawning ground). Wet land - including lowland swamp - is crucial for the ecological functions and environmental services, to prevent environmental pollution or as the "natural cleaner". With that reason, we need to preserve swampland ecosystem.

The development of oil palm plantation in South Kalimantan of 2006-2010 showed 35.05\% increasing, but unfortunately if viewed from the oil palm plantation ownership mostly dominated by private plantation by $81.96 \%$, while the community plantation only $17 \%$, and state plantation by $1.50 \%$.

Imbalance ownership structure of oil palm plantation in South Kalimantan continue to increase, with 701.876 ha area of the development plan (Norbah, 2011) included the swamp development plant of 217.270 ha which is aimed for the private plantation companies. It means most community livelihood of the swamp areas would 
change.

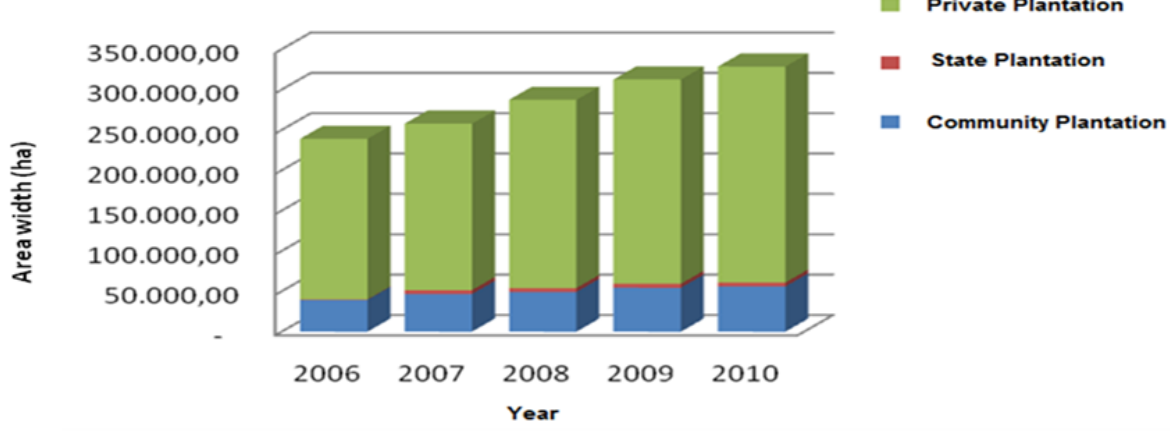

Figure 1. Development area of oil plantation in South Kalimantan

The presence of big companies is mastering most area and become potential conflict on social, economic and cultural for local inhabitant. They have not conditioned socially and culturally by related governmental institution. In 2012, there are 22 companies with target area of 217.269 ha that is distributed in 6 regencies. These companies have developed and invested on the oil palm plantation in swamp area. However, only about 33.719 ha are realized (Norbah, 2011). If the business plan has been done, then the company will take active role on protecting the environment, not only bring profit for the company but also give benefit to the society (Aimkij et al., 2013).

For the local government, investment on oil palm plantation bring expectation and opportunities to increase the production, foreign exchange, income distribution, work opportunities, area development and economic growth. Otherwise, societies expect increase on their income and welfare. Nevertheless, emerged impacts from the change of swamp use and function (as the natural resources for the development of oil palm plantation) cause pressure for the swamp ecosystem with various implications, either to the ecological aspects, social, economic, and cultural or environmental problems (Obiefuna, 2013). The change of land-function is planted food crop as the main income resources into oil palm plantation. These problems were also disrupted the environmental equilibrium and created social conflicts between companies and communities. It is also related to the environmental impact due to the land preparation, water management, nutrients and fertilizer, pest and plants diseases control. Therefore, local government should improve their concern and emphasize the importance of proactive control system to decrease the future threat and risk (Pavri et al., 2012).

The Constitution of 1945 stated that efficient use of the natural resources for public welfare is suitable with the functions, should be wisely managed so that the development and the sustainability of present and future of human life can be preserved. Turner and Pearce (1991) stated that the natural and environmental resources not only have direct utilization value in, but also has indirect value, future value and non consumptive value. Research on economic value of the natural and environmental resources, especially at the swampland ecosystem, is comprehensively become crucial. Because it will give total economic value from the resources and become the technical instrument that can be used to calculate not only the direct economic benefit but also the indirect benefit. So, with the valuation assessment for certain area would help policy maker inside the government in decision making that related to the management and the use of swampland area.

\section{Method}

The research used qualitative approach. The research site was purposive sample of the swampland as oil palm plantation area in Tapin Regency, South Kalimantan. There are seven (7) companies that will develop the oil palm plantation of 60.874 ha. There are also economic activities of the society that use the swamp.

\subsection{Data Collection}

Primary data were obtained from field survey with questionnaire and observation, while secondary data obtained from several governmental and private institutions (companies), literature and researches' publication. Results and observation were collected from various resources such as report of Department of Plantation, Research Center of Oil Palm and some plantation companies in conducting their business. Environmental data is based on the previous research results, about the economic-ecological value of swampland ecosystem in Tapin Regency. The information on data of investment and oil palm plantation collected by several basic assumptions and literature study, and compared the financial feasibility study (report of financial study in Banks) of some 
plantation companies. This study is also a basic calculation case for economic valuation analysis on oil palm investment in swampland area. We used assumption as follows:

1. The width of oil palm area is 10.000 ha

2. Companies should construct the processing factories to manage the fresh palm fruit bunches become palm oil (CPO - Crude Palm Oil and KPO - Kernel Palm Oil)

3. Production capacity are 60 tons of fresh palm fruit bunches per hour

4. Plants' productive period is 25 years, with gestation period of four years

5. Production level of fresh palm fruit bunches are 20-29 tons per ha

6. Fresh palm fruit bunches extraction level to become CPO is $24 \%$ (maximum)

7. Fresh palm fruit bunches extraction level to become $\mathrm{KPO}$ is $5.5 \%$ (maximum)

\subsection{Data Analysis}

Economic valuation and modeling analysis were combined to give perception and complete the sustainability and optimized wet land management (Turner, 2000). Calculation and analysis of oil palm plantation investment in swampland area are done with follow stages:

First, we used valuation method approach for identifying the benefit and total economic value of swampland function, with formula (CSERGE, 1994;, Lucky, 2004; Manurung, 2011):

$$
T E V=U V+N U V=(D U V+I U V+O V)+(E P)+(S V)
$$

Description:

$\mathrm{TEV}=$ total economic value $\mathrm{DUV}=$ direct value in use $\quad \mathrm{EP}=$ existence value

$\mathrm{UV}=$ value in use $\quad \mathrm{IUV}=$ indirect value in use $\quad \mathrm{SV}=$ social value

NUV = non value in use $\quad \mathrm{OV}=$ optional value

Second, calculating and analyzing the oil palm plantation investment in swampland area without including the environmental and social values. Third, calculating and analyzing the oil palm plantation investment in swampland area by including economic, environmental and social values.

In the management of natural and environmental resources, economic valuation of oil palm plantation investment and functions of the swampland area is adopted from the calculation of Natural Resources Management (NRM). NRM is started with the calculation of the financial income from the Direct Use Value (DUV), or Indirect Use Value (IUV) with Benefit Cost Ratio (BCR) model. We also used Net Present Value (NPV) and Internal Rate of Return (IRR) for the valuation method from certain activities that can be considered as financial and economic feasibility, which is using model (Abelson, 1979; CSERGE, 1994).

\section{Results and Discussion}

\subsection{Cost Investment Analysis}

Total cost per year on activities implementation is the combination of investment, operational and maintenance cost that correspond to the activities implementation schedule. Investment cost includes plants, non plants and construction of processing factory investment cost.

Cost calculation of plants investment based on the maximum cost unit to widen the oil plant plantation in wetland that issued by General Directorate of Plantation Decree No. 149/Kpts/RC.110/6/2011, about maximum cost unit of oil palm plantation in wetland. Unit for South Kalimantan area on maximum investment cost of immature plants from $0-3$ year is Rp. 55.356.000, - or US\$5827 per ha.

The plants investment consisted of land clearing cost, oil palm seedling, infrastructure construction, drainage construction, planting, fertilizing, pest and diseases control, channel maintenance, sanitation, land conservation, weeding, infrastructure maintenance, insertion and fee management. Otherwise, non plants investment consist of base camp construction, housing and office building, vehicles and heavy equipments, machines, road and bridges, and overhead cost average of Rp. 15.386 .000 ,- or US\$ 1620 per ha. So, total investment cost of plants and non plants are Rp. 70.74 millions or US\$ 7447 per ha.

The study besides calculating the plants and non plants investment cost, also included the oil palm factory investment according to the Ministry of Agriculture Decree No. 357/Kpts/HK.350/2/2002. This decree stated that the processing factory for plantation harvest is integrated part that should be constructed by company, with the assurance of fresh fruit production or raw materials from their own plantation. 
Cost calculation on the construction of oil palm factory is strongly determined by the capacity of processing factory, while the factory capacity is determined by the production profile or monthly maximum production or production distribution in a year. The used capacity of the processing factory machines is based on the monthly maximum production of $12.5-13 \%$ from annual total production. Therefore, 10.000 ha plantation will produce annual maximum production of 290.000 tons fresh fruit bunches (Supplement 2) that would need processing factory with capacity of 60 tons fresh fruit bunches (FFB) per hour that obtained with Wahyono et al. (2007) formula.

$$
\text { Factory capacity }=\frac{\text { One year total production } \times 12.5 \%}{25 \times 20} \mathrm{x}+\text { ton of FFB / hour }
$$

The construction of oil palm plantation processing factory with these capacity, need more cost than Rp 126 billion or US\$ 13.36 million, with dollar exchange to rupiah $\mathrm{Rp} 9.500$, -. The calculation results and literature study showed that to build 10.000 ha of oil palm plantation needs investment cost that displayed in Table 1 .

Table 1. Investment Cost of 10.000 ha Oil Palm Plantation

\begin{tabular}{ccc}
\hline Investment & Rupiah per ha & US Dollar per ha \\
\hline Plants & 553.56 billion & 582 \\
Non plants & 153.86 billion & 1620 \\
Total investment of plants and non plants & 70.74 million & 774 \\
Investment of processing factory @ 60 tons FBB per hour & 126.90 billion & 13.36 million \\
\hline
\end{tabular}

Implementation of investment construction plantation were done by assuming the financial resources from private capital equity of $35 \%$ ( $R p 292.01$ billion) and 65\% (Rp 542.32 billion) from other investment cost in the form of bank loan, from total investment of Rp 834.32 billion. With the commercial interest of $13 \%$ per year, then the repayment period is 12 years with grace period of 4 years.

\subsection{Production Cost Analysis - Operational}

Operational cost of 10.000 ha plantation and operation of processing factory per cycle of 27 years need cost $\mathrm{Rp}$ 3.94 trillions. The total cost consisted of productive plants (PP) treatment, harvesting and transportation (plantation to processing factory), processing, transportation of $\mathrm{CPO}$ and $\mathrm{KPO}$ to the port, and marketing.

Average treatment cost of the productive plants (PP) in Rp 8.801 .000 per ha per year. It consist of the cost of fertilizing, pest and diseases control, duct maintenance, soil conservation, weeding, infrastructure maintenance, harvest and transport from plantation to the processing factory. The cost ranged between Rp 250 - Rp 300 per $\mathrm{kg}$ of FFB depend on the mileage. The average processing cost is Rp 150 per kg FFB, average transportation cost to the port is Rp 200 per $\mathrm{kg}$ (CPO - Rp 65 and KPO - Rp 135). The cost is according to the Regulation of Agriculture Minister No. 17/ 2010 and Regulation of South Kalimantan Governor No. 29/ 2010.

\subsection{Revenue Analysis}

Revenue or investment benefit of the oil palm plantation for a cycle is determined by the width of planting area, plants productivity (production profile), extraction of fresh fruit bunches (FFB) become crude palm oil (CPO) and kernel palm oil (KPO), and the prevailing selling price.

Production profile of palm oil is determined by the plants productivity for a cycle which begun from the oil palm start to production until the plant replanted. The productivity level of oil palm is determined and influenced by genetic factors of the seeds, environmental factors, the suitability of land and the plantation management. The red-yellow podsolic of mineral soil in Kalimantan generally is categorized as land suitability of class 3 (Pahan, 2008). Total benefit per year that is received is the summation from all revenues in a year, during the activities period. The revenue in cash, obtained from the selling of CPO and KPO that sold either in domestic or export market.

\subsection{Selling Price of CPO and KPO}

In 2011, the average CPO price was US\$ 1200 per ton, but in the beginning of 2012, the CPO price was opened decrease compared with the 2011, on level US\$ 1.000 per ton. Then slightly increase into US\$ 1.182 per ton on April 2012, then decrease becomes US\$ 837 per ton at the Rotterdam market. CPO market at the international market of Malaysia in December 2012 tend to decrease at RM 2.284 per ton - equivalent with US\$ 747.46 per 
ton (1US\$ = RM 3.0557). The price is the lowest CPO price for 2012 (Arifenie and Baskoro, 2012). Based on that information, we calculate the selling price of CPO for US\$ 800 per ton, while for kernel extract price before become KPO is assumed 55\% from the CPO price, and fixed for per cycle.

\subsection{Financial Analysis of Oil Palm Plantation Investment in Swampland Area}

Financial analysis aimed for valuing whether certain activity is feasible financially, or capable to give financial profit for the company that objective to maximize their profit. Supplement 2 showed the cash flow on the construction of oil palm plantation during the period of plantation plants.

The results on data analysis showed that the total revenue of the company come from the CPO and KPO sales started from 3rd - 27th year, with total revenue of Rp 10.59 trillion or about Rp 28 billion - Rp 590 billion per year, or Rp $9.4-59.01$ million per year. Otherwise, the total production cost during activities of 5.35 trillion (investment and operational. or average Rp 198.31 billion per year, or Rp 19.83 million per ha per year. Based on that revenue and cost data then we calculated the profit, i.e. Rp 5.24 trillion or Rp 1.517.284 per ha per month.

Cash flow (Supplement 2), with assumption of 13\% discount rate, then the financial feasibility of the investment showed positive Net Present Value (NPV) of Rp 658.14 billion or US\$ 69.28 million. The benefit cost ratio (B/C) is 1.44, Net B/C 3.07 and Internal Rate of Return (IRR) is 27.35\%, and Payback Period (PP) is in the 10th year.

Other interpretation is with $19 \%$ discount interest rate that smaller than $27.35 \%$ internal rate of return and net $\mathrm{B} / \mathrm{C}$ 1.82. It means that the business activities of plantation with scale of 10.000 ha in swampland area is financially feasible because it would bring profit for company. However, the value did not consider the environmental and social aspects (total economic value of swampland area), that emerge from the plantation business.

\subsection{Analysis of Economic Valuation of Oil Palm Plantation in Swampland Area}

Economic values calculated from the direct use value (DUV), indirect use value (IUV) and optional value (OV) totaled economic value of the swampland ecosystem in Districts of Central Tapin and South Candi Laras, in Tapin Regency for 10.000 ha. The total economic value of swampland ecosystem (environment and social) showed Rp 232.570.833.400 (US\$ 24.481 per year) that consist of (Hamdani et al., 2012):

Table 2. Economic value of Swampland Ecosystem

\begin{tabular}{lrrc}
\hline \multicolumn{1}{c}{ Value } & Rupiah (Rp) & US Dollar (\$) & $\begin{array}{c}\text { Percentage (\%) from } \\
\text { all Economic and } \\
\text { Environmental value }\end{array}$ \\
\hline Direct use & 16.205 .201 .887 & 1.71 millions & 6.97 \\
Indirect use & 207.244 .129 .144 & 188.301 & 89.11 \\
Optional & 1.778 .640 .000 & 187.225 & 0.76 \\
Cultural heritage existence & 1.788 .862 .069 & 188.301 & 0.77 \\
Social & 5.554 .000 .350 & 584.632 & 2.39 \\
\hline
\end{tabular}

Total Economic Value (TEV) from the swampland ecosystem is the real value or real price of the ecosystem and also the real cost that should be invested for swampland ecosystem conservation or cost that should be calculated in the development of the plantation. It is different with the financial analysis. The economic valuation analysis of environmental and social cost or the potentials economic and ecological value is included in valuing and deciding the feasibility of the plantation investment.

The feasibility criteria of the investment are similar with the financial valuation. The total economic value included environmental and social cost - with assumptions of static prices and factors. It showed that the economic valuation of the plantation investment in 10.000 ha swampland area on the $13 \%$ discount rate produces NPV of minus Rp 855.97 billion or minus US\$ 90.10 million, and B/C ratio of 0.71 . It means the investment is not feasible (Supplement 3).

Based on the matter above, the environmental and social cost influence the NPV calculation, or determining the investment feasibility. In another hand, government has determined that the oil palm is one superior commodities of plantation in Indonesia. Therefore government continuously encourages the business, and tries to anticipate 
the environmental problems through various regulations for the companies that eager to open oil palm plantation. In our research, we attempt to decrease the negative impact or make the project investment become feasible, or positive NPV, and then the environmental factor or the environmental and social cost should be decreased. The scenario of decreased environmental and social cost is indeed difficult to be appropriately and exactly assessed. Therefore, we used the Break Even Analysis to assess the total value of environmental and social costs that make the NPV of oil palm plantation become zero. Zero NPV means the project only deliver the principal break-even, or do not provide profit or financial loss for the investors.

Based on the analysis, NPV will be zero, if the environmental and social cost is Rp 9.025 .541 per ha per year or about US\$ 950.06 per ha. The number means that if the environmental cost smaller or same with the NPV, then the plantation investment become feasible. The second scenario is if the CPO price higher or same with US\$ 1300 per ton. However, the price scenario is difficult, because the CPO price is determined by the world price, although Indonesia is the biggest producer in the world, Indonesia is unable to determine the price itself.

\section{Conclutions}

The plan on function-change of swampland area into other function by changing the existing pattern, is assumed to bring negative impact, e.g. decreased plant production, decreased fish catch, loss of job opportunities, and loss of income from Galam (Melaleuca leucadendron Linn) wood, Purun (Eleocharis dulcil) plants. It also caused the loss of water resources for households, extinction of biological diversity, and the emergent of social problems such as land conflict.

The total economic value of swampland ecosystem is Rp 232.570.833.400 (US\$ 24.48 millions) per year. It is the benefit or the real price (environment and social) of the swampland ecosystem. It also calculated as the real price that should be invested on the plantation. The fact is that this value actually never been calculated in the feasibility valuation by the companies. If the total economic value or environmental and social cost is calculated based on economic valuation analysis, then the development of plantation in the swampland area have not feasible decided yet. Based on the sensitivity analysis calculation, the feasibility of oil palm plantation investment in the swampland area is strongly influenced by the total value of environmental, social cost, and the $\mathrm{CPO}$ price in the world wide market.

\section{Suggestions}

We suggest the government and the creditor to consider and calculate the economic-ecological values or environmental and social values in decision making on plantation opening license. We also suggest analyzing the feasibility of the land function-change from swampland into oil palm plantation.

\section{References}

Abelson, P. (1979). Cost Benefit Analysis and Environmental Problem. In Technical Specification Report of Compilation of Balance and Economic Valuation of Coastal and Sea Resources. Survey Center of Bakorsutanal Sea Nature. 2003. (http://www.scrbd.com/doc/41805763/compilation of Balance and Economic Valuation of Coastal and Sea Resources).

Aimkij, N., Mujtaba, B. G., \& Kaweenkinsutrakul, T. (2013). Green Management Sustainability and Its Economic Impact. Journal of Economic and Sustainable Development, 4(6), 104-115.

Arifenie, F. N., \& Baskoro, S.. (2012). CPO Prices in 2013 cannot exceed the 2011 price. Retrieved December 13, 2012, from http://industri.kontan.co.id/news/harga-cpo-di-2013-tak-bisa-melampaui-harga-2011

BPN Kalsel. (2011). Digitization on Screen. Map of Plantation Business. Map of RBI Bakosurtanal. 1991 Edition.

CSERGE (The Centre for Social and Economic Research on the Global Environment). (1994). Economic Value and the Environment in the Development Wolrd, a Report to the UNEP, Nairobi.

Directorate General of Plantation Agriculture Ministry. (2011). Decision No. 149/Kpts/Rc.110/2011. On The Unit Cost of Maximum of Plantation Development in Wetland Revitalization Program 2011.

Hamdani, H., Imam, H., Anwar, F., Luthfi, F. A., \& Budi, S. (2013). Economic-Ecological Value of Non-Tidal Swamp Ecosystem (Case Study of Tapin District, Kalimantan Indonesia). Modern Applied Science, 8(1). Canadian Center of Science and Education.

Lucky, A. M., \& Yudi, W. (2004). The Introduction of the Concept and Methodology of Economic Valuation of Coastal and Marine Resources. Bogor Agricultural University, Bogor.

Manurung, E. G. T. (2011). Analysis of Economic Valuation of Indonesiaan Palm Oil Plantation. Environmental 
Policy and Institutional Strengthening IQC (EPI).

Noor, M. (2007). Swamp of Lebak: Ecology, Utilization and its Development. Division of High Education. PT. Raja Grafindo Persada, Jakarta.

Norbah, S. (2011). Plantation Development Policy in South Kalimantan. Plantation Development Coordination Workshop Policies on Palm Oil Development on Wetlands, South Kalimantan, 22 November 2011.

Obiefuna, J. N., Nwilo, P. C., Atagbaza, A. O., \& Okolie, C. J. (2013). Spatial Changes in the Wetlands of Lagos/Lekki Lagoons of Lagos, Nigeria. Journal of Sustanaible development, 6(7), 123-133. Canadian Center of Science and Education. Retrieved from http://www.ccsenet.org/journal/index.php/jsd/article/view/22379

Pahan, I. (2008). Complete Manual of Oil Palm, Agribussiness Management, Upstream to Downstream. Panebar Swadaya. Jakarta.

Pavri, F., Anna, S., Abrahamm D., \& Jeand, D. M. (2012). Land Use and Socioeconomic Influences on a Vulnerable Freshwater Resource in Northern New England, United States. Environmental, development sustainability, 15(3), 625-643. http://dx.doi.org/10.1007/s 10668-012 9397-x

Roy, M. B., Roy, P. K., Samal, N. R., \& Mazumdar, A. (2012). Socio-Economic Valuations of Wetland Based Occupations of Lower Gangetic Basin through Participatory Approach. Environment and Natural Resources Research, 2(4), 30-44. http://dx.doi.org/10.5539/enrr.v2n4p30

Sabran, M., Maamun, M. Y., \& Fagi, A. M. (1998). Potency and Constraints in Development of Food Crop Farming in Kalimantan Swampland. Proceedings of Workshop on Regional Development strategy in Kalimantan. Installation of Agricultural Research and Technology Assessment of South Kalimantan. Banjarbaru.

Swimpton, S. M., Lupi, F., Robertson, G. P., \& Landis, D. A. (2006). Ecosystems Services from Agriculture: Looking Beyond the Usual Suspects. American Journal of Agricultural Economics, 88(5), 1160-1164.

Turner, K., \& Pearce, D. (1991). Economics of Natural Resources and the Enviroment. The Johns University Press.

Turner, R. K. (2000). Valuation of Wetlands in a Landscape and Institutional Perspective. Ecological Economics, 35, 1-6. http://dx.doi.org/10.1016/S0921-8009(00)00163-4.

Turpie, J., Lannas, K., Scovronick, N., \& Louw, A. (2010). Wetland Ecosystem Services and Their Evaluation: A Review of Current Understanding and Practice. Wetland Valuation 1, Water Research Commission Report No. TT 440/09.

Wahyono, T., Kabana, M., \& Djafar, S. (2007). Economic Investment Palm Oil Mills. (Economic outlook palm). Palm Oil Research Center, Medan.

\section{Copyrights}

Copyright for this article is retained by the author(s), with first publication rights granted to the journal.

This is an open-access article distributed under the terms and conditions of the Creative Commons Attribution license (http://creativecommons.org/licenses/by/3.0/). 